\title{
INFESTATION OF ONION BULBS WITH Eumerus amoenus LOEW. (DIPTERA: SYRPHIDAE) DURING STORAGE
}

(Received:10.8.2006)

\author{
By \\ H. H. Mahmoud, ${ }^{*}$ S. I. El-Sherif, H. A. El -Shabrawy \\ and S. A. Mourad * \\ Department of Economic Entomology and Pesticides Sciences, Faculty of Agriculture, Cairo University, \\ Giza, Egypt \\ * Plant Protection Research Institute, Agricultural Research Centre, Dokki, Giza, Egypt
}

\begin{abstract}
Onion (Allium cepa L.) is subjected to the attacks of certain insect pests during storage period, which extends from early June until early November; including those belonging to the genus Eumerus particularly the onion bulb fly Eumerus amoenus Loew. (Diptera: Syrphidae). This investigation aimed at evaluating the efficacy of six different storage methods; three outdoor (bulbs on the soil, bulbs on the soil covered with hay and bulbs in perforated plastic sacks) and three indoor (bulbs on the floor, bulbs on shelves and bulbs in perforated plastic sacks) on onion bulbs infestation with E. amoenus throughout the three successive storage seasons of 2003- 2005 at Assuit Governorate using the variety "Giza 6 Mohassan". The effect of frequent discarding of bulbs infested with E. amoenus on the \% infested bulbs and yield loss was also investigated.

Storing bulbs indoor decreased infestation than their storage outdoor. Onion bulbs stored outdoor on the soil received the highest infestation $(23.0-36.5 \%)$ while storing them in sacks either outdoor or indoor recorded the least infestation (10.0-19.0\% and 11.0-14.5\%, respectively). Discarding infested bulbs decreased infestation percentage by about 6-14\%.The relationship between \% bulb infestation and yield loss was highly significant $(\mathrm{r}=0.994-0.999$ and $\mathrm{b}=0.63-0.77)$. A change of $10 \%$ in the $\%$ infested bulbs alters yield loss by approximately $6-8 \%$.
\end{abstract}

Key words: Allium cepa ,Eumerus amoenus, , infestation ,onion, onion bulb fly .

\section{INTRODUCTION}

In Egypt, onion (Allium cepa L.) is an important field crop. According to the Department of Statistics of the Ministry of Agriculture and Land Reclamation, the total area cultivated with onion in 2005 exceeded one hundred thousand feddans that produced over 1.3 million tons of bulbs which cover the requirements for both local consumption and exportation. Onion is cultivated in several governorates especially in Upper Egypt and different methods are practiced to store its bulbs .Stored onion bulbs are subjected to the attacks of certain insect pests, the most prominent of which is the onion bulb fly, Eumerus amoenus Loew. (Diptera: Syrphidae) and Eumerus vestitus Bezzi which is less economically important (ElShabrawy, 1996). Onion is seeded in August and September, transplanted in October and November and harvested in April and May. Farmers and stock sellers usually store harvested bulbs from June until October. Bulbs are stored either outdoor in the open or indoor in stores. In the field, onions are stored in heaps on the soil, heaps on the soil covered with wheat or rice hay or in sacks .In stores, storage takes place in heaps on the floor, on shelves or in perforated plastic sacks.

Due to the frequently noticed damage caused by E. amoenus to onion bulbs, particularly during the storage period, the current investigation was suggested.It concentrated on evaluating the efficacy of six different storage methods (three indoor and three outdoor) for protecting onion bulbs from $E$. amoenus damage as well as the effect of frequent discarding of infested bulbs on infestation rate and yield losses.

Literature on E. amoenus and its infestation to onion bulbs during storage is apparently few. Most of the work done in this respect was carried 
out in Egypt by El-Sherif (1971) and Abd-ElFattah (1980) who reported reasonable protection against E. amoenus by storing bulbs at $0-2 \mathrm{C}^{0}$ and $90 \%$ R. H. Mohamad (1973) and Mikhael (1978) reported that infestation with E. amoenus reaches its peak by the beginning of July while ElShabrawy (1990) recorded two peaks of $E$. amoenus ; one in July and the other by midAugust, Massry (2002) mentioned that, during storage, bulb infestation with $E$. amoenus reaches 5-30 \%. Scattered studies were also conducted abroad on other species of the genus Eumerus .Zabirov (1963), in USSR, observed that onion bulbs are infested with E. strigatus and $E$. tuberculatus. Mulin (1990) and Marcos et al.(1999) in USSR and Spain, estimated the loss in onion bulbs infested with E. strigatus at 25-30\% and $45-85 \%$, respectively .

\section{MATERIAL AND METHODS}

Experiments on the effect of E. amoenus infestation on onion bulbs during the storage period were conducted at Assuit Governorate throughout the three successive years 2003-2005 using the commonly cultivated onion variety "Giza 6 Mohassan ".

\subsection{Effect of storage method on bulb infestation}

Six quantities of onion bulbs, each weighing $100 \mathrm{~kg}$., were collected from the field at the beginning of the storage season (early June) for each of the three years of investigation. One of these quantities was stored under one of the following six different storage methods: A) outdoor methods: bulbs stored on the soil, bulbs stored on the soil and covered with wheat hay, and bulbs stored in perforated plastic sacks. B) indoor methods in clean stores: bulbs stored on the floor, bulbs stored on shelves at what height, and bulbs stored in perforated plastic sacks. The bulbs of each quantity were then divided into four equal subquantities of $25 \mathrm{~kg}$. each and regarded as replicates. Monthly samples of 10 bulbs / replicate were collected at random and inspected for infestation with E. amoenus. Sampling continued from late June until late October and thus a total of 5 samples / treatment was taken. Comparison between tested storage treatments was based on the analysis of variance, F test and L.S.D.

\subsection{Effect of frequent discarding of infested bulbs on infestation}

For every considered year, onion bulbs were randomly collected from the field by early June. Three random quantities (treatments) of bulbs each weighing $40 \mathrm{~kg}$. were piled and every pile was divided into four subquantities of $10 \mathrm{~kg}$. each (replicates). All subquantities were then stored on the floor of a clean store until the end of the season by late October. The bulbs (4 replicates) of each of the three piles were subjected to one of the following three treatments: A) bulbs inspected and infested ones discarded, B) bulbs inspected without discarding infested ones. C) bulbs totally protected from infestation using Furan $10 \%$ granules at a rate of $50 \mathrm{gm}$. / replicate added at the beginning of the experiment and again every 15 days. Examining bulbs for E. amoenus infestation was practiced twice: once by late August (2months after storage) and again by late October (4-months after storage). At every inspection date, the sound and infested bulbs in treatments A (bulbs inspected and infested ones discarded) and B (bulbs inspected without discarding infested ones) were counted and weighed. The bulbs of treatment $\mathrm{C}$ (control) were also weighed at every inspection date.

The percentage of infested bulbs, percentage of actual weight loss, percentage of humidity loss and percentage corrected weight loss for each tested treatment were then calculated by applying the following set of formulae:

$\%$ infested bulbs $=\frac{\text { No. of infested bulbs }}{\text { Total no. of bulbs }} \times 100$
$\%$ actual weight loss $=$

\footnotetext{
Weight at the beginning of the storage period - weight at inspection date $\quad$ X100

Weight at the beginning of the storage period

$\%$ humidity loss =

Weight of bulbs in the control treatment at the beginning

of the storage period - weight of bulbs in the control

treatment at inspection date

X100

Weight of bulbs in the control treatment at the

beginning of the storage period

$\%$ corrected weight loss $=\%$ actual weight loss $-\%$ humidity loss

\subsection{Loss assessment}

Suitable quantities of onion bulbs, more or less of similar size, were stored into a clean store at the beginning of each considered storage season i.e.,early June. One month later, all bulbs were examined for E. amoenus infestation to separate infested ones. Separated infested bulbs were then used for inducing different levels of infestation with the fly through mixing uninfested and infested bulbs at certain specified infestation rates (percentages). Eleven induced infestation levels were tested to represent ; $0,10,20,30,40,50$, $60,70,80,90$ and $100 \%$ infestation . Fourty bulbs were devoted for each tested infestation level. Bulbs were divided into 4 equal groups of 10 bulbs each (replicates). Zero infestation level consisted of 10 sound bulbs / replicate and $100 \%$ infestation level consisted of 10 infested bulbs / 
replicate. Intermediate infestation levels were induced by adjusting the proportions of sound and infested bulbs for each replicate. For example, to induce $30 \%$ infestation, each replicate for this particular level consisted of 7 sound bulbs and 3 infested ones. The bulbs of each replicate were packed in a tightly tied perforated cloth bag and stored in a clean store. The bags were inspected and weighed three times by early July, early September and early November (1, 3 and 5 months after the beginning of storage, respectively) . To maintain the percentage of bulb infestation constant at the specified infestation level, the percentage of infestation was regularly adjusted at every examination date by discarding the excessive infested bulbs and replacing them with sound ones of (nearly) similar size. Loss assessment was then estimated by applying the following formula:

$\%$ Weight loss=

Weight of control treatment - Weight of treatment $\times 100$

Weight of control treatment

To determine the effect of infestation rate on weight loss, the simple correlation and regression coefficients for $\%$ weight loss on $\%$ infestation were calculated.

\section{RESULTS AND DISCUSSION}

\subsection{Effect of storage method on bulb infestation}

The effect of storage method on the monthly mean numbers of onion bulbs infested with the onion bulb fly $E$. amoenus throughout the three successive years 2003-2005 is summarized in Table (1). Table (2) shows the mean percentages of infested bulbs for 2003-2005 under the different tested storage methods. Bulbs stored outdoor were subjected to a relatively higher infestation than those stored indoor (2.3-18.7 / 40 bulbs \& 10.0$36.5 \%$ infested bulbs and 2.3-8.7 / 40 bulbs \& 12.0-17.5\% infested bulbs, respectively).

As seen in Table (1), for outdoor storage, infestation tended to increase from June until September (from 2.3 to 16.0 / 40 bulbs). During October, infestation continued to increase among the bulbs stored on the soil (18.7 / 40 bulbs) whereas it decreased among those covered with hay (7.0 / 40 bulbs) or stored in perforated plastic sacks (6.3 / 40 bulbs). During the three considered years, the peak of infestation with $E$. amoenus under outdoor storage took place by the end of September for bulbs covered with hay or stored in perforated plastic sacks (13.7 and 9.0 / 40 bulbs, respectively) and about a month later for the bulbs stored on the soil (18.7 / 40 bulbs). For indoor storage, infestation increased between June and August to reach peaks of $8.3,8.7$ and 7.0 bulbs / 40 bulbs for storage on the floor, shelves and in perforated plastic sacks, respectively, by the end of August. Infestation declined throughout September and October for the three tested indoor storage methods $(6.7,5.3$ and 6.7 bulbs / 40 bulbs for storage on the floor, shelves and in perforated plastic sacks, respectively). El-Shabrawy (1990) reported that, in Giza Governorate, E. amoenus has two peaks; one during the first week of July and the other in mid August. Massry (2002) mentioned that, in Alexandria Governorate, infestation with $E$. amoenus reaches its maximum between late July and early August.

The analysis of variance indicated that the differences between the six tested storage methods in respect of onion bulb infestation with $E$. amoenus were highly significant. Storage of bulbs outdoor either on the soil or covered with hay recorded the maximum infestation (11.7 and 9.4 bulbs / 40 bulbs, respectively) and both storage methods were statistically insignificant from each other. Storage in perforated plastic sacks outdoor as well as all tested indoor storage methods were less susceptible to infestation and insignificantly different from each other $(5.4,6.3,5.5 \& 5.1$ bulbs / 40 bulbs and 13.6, 15.8, 13.7 and $12.7 \%$ infested bulbs for storage outdoor in perforated plastic sacks and storage indoor on the floor, on shelves or in perforated plastic sacks, respectively, Tables (1\&2).

The above data lead to the general conclusion that the storage of onion bulbs in stores protects them from E. amoenus infestation. However, storage of bulbs in perforated plastic sacks outdoor provides an almost similar protection. For indoor storage, keeping bulbs on shelves seems to provide a better protection against E. amoenus than keeping them on the floor while storage in sacks provides a relatively better protection. It is recommended, therefore, to store onion bulbs indoor in perforated plastic sacks rather than outdoor under any storage conditions to minimize their infestation with $E$. amoenus throughout the storage season. 
Table (1): Monthly mean numbers of infested bulbs / 40 bulbs under six different storage methods (means for three successive years, 2003-2005).

\begin{tabular}{|c|c|c|c|c|c|c|}
\hline \multirow{3}{*}{ Month } & \multicolumn{6}{|c|}{ Storage method } \\
\hline & \multicolumn{3}{|c|}{ Outdoor } & \multicolumn{3}{|c|}{ Indoor } \\
\hline & $\begin{array}{l}\text { On the } \\
\text { soil }\end{array}$ & $\begin{array}{c}\text { On the soil } \\
\text { covered } \\
\text { with hay } \\
\end{array}$ & Sacked & $\begin{array}{l}\text { On the } \\
\text { floor }\end{array}$ & On shelves & Sacked \\
\hline June & 5.0 & 6.3 & 2.3 & 4.0 & 2.3 & 2.3 \\
\hline July & 6.0 & 8.7 & 3.3 & 5.3 & 4.3 & 2.7 \\
\hline August & 13.0 & 11.3 & 6.3 & 8.3 & 8.7 & 7.0 \\
\hline September & 16.0 & 13.7 & 9.0 & 7.3 & 6.7 & 6.7 \\
\hline October & 18.7 & 7.0 & 6.3 & 6.7 & 5.3 & 6.7 \\
\hline Mean & $11.7^{\mathrm{a}}$ & $9.4^{\mathrm{ab}}$ & $5.4^{b}$ & $6.3^{b}$ & $5.5^{b}$ & $5.1^{b}$ \\
\hline $\mathrm{F}_{\text {Cal. }(0.05)}$ & \multicolumn{6}{|c|}{3.27} \\
\hline $\mathrm{F}_{\text {Tab. (0.05) }}$ & \multicolumn{6}{|c|}{2.62} \\
\hline L.S.D. $(0.05)$ & \multicolumn{6}{|c|}{4.380} \\
\hline
\end{tabular}

Table (2): Mean \% of infested bulbs for 2003-2005 under six different storage methods.

\begin{tabular}{|c|c|c|c|c|}
\hline \multirow{2}{*}{\multicolumn{2}{|c|}{ Storage method }} & \multicolumn{3}{|c|}{ Mean \% infested bulbs } \\
\hline & & 2003 & 2004 & 2005 \\
\hline \multirow{3}{*}{$\begin{array}{l}\overline{0} \\
\text { 음 } \\
\frac{1}{3} \\
0\end{array}$} & On the soil & 23.0 & 28.5 & 36.5 \\
\hline & $\begin{array}{l}\text { On the soil covered with } \\
\text { hay }\end{array}$ & 17.5 & 21.5 & 31.5 \\
\hline & Sacked & 19.0 & 10.0 & 12.0 \\
\hline \multirow{3}{*}{$\begin{array}{l}\overline{0} \\
\text { 음 } \\
\underline{0}\end{array}$} & On the floor & 17.5 & 13.0 & 17.0 \\
\hline & On shelves & 12.0 & 13.5 & 15.5 \\
\hline & Sacked & 14.5 & 11.0 & 12.5 \\
\hline
\end{tabular}

\subsection{Effect of frequent discarding of infested bulbs on infestation}

Usually, onion growers and stock sellers practice discarding the bulbs infested with $E$. amoenus during the storage season. Such discarding is oftenly practiced once or twice during the storage period almost every 2 months. The practicability of such practice and its effect on the percentage of infested bulbs and yield loss was investigated (Table3). For the three considered years, discarding infested bulbs twice throughout the storage season decreased the percentage of infested bulbs at the end of the storage season by 5.8-7.0\%, with a grand mean of $6.3 \%$ compared to mean infestation percentages of $12.6-15.0 \%$, with a grand mean of $13.8 \%$ when infested bulbs were not discarded .

Table (3) shows also that yield reduction ranged between 7.7-9.7 \%, with a grand mean of $8.7 \%$ in the case of discarding infested bulbs twice whereas non - discarding of the infested bulbs resulted in a yield loss of $11.2-17.0 \%$ with a grand mean of $13.5 \%$. Results emphasize that the process of discarding infested bulbs once two months after the beginning of the storage season and again two months later decreases infestation percentage approximately from about $14 \%$ to $6 \%$ and yield loss from about $14 \%$ to $9 \%$.In conclusion , it might be recommended to inspect stored onion bulbs as much as possible throughout the storage season and discard infested bulbs to help decreasing both $\%$ infested bulbs and yield loss .

\subsection{Loss assessment}

Table (4) shows the effect of \% bulb infestation with $E$. amoenus on yield loss based on the annual grand means of infestation for the three successive onion storage years 2003-2005. Results confirm a highly significant positive correlation between $\%$ bulb infestation and yield loss $(r=0.994-0.999)$. The simple regression coefficient for such relationship ranged 0.63-0.77. In other words, an increase or decrease of $10 \%$ in $\%$ bulb infestation alters $\%$ yield loss by approximately 6-8 \%. 
Table (3): Effect of discarding onion bulbs infested with $E$. amoenus on the mean percentage of infested bulbs and yield loss.

\begin{tabular}{|c|c|c|c|c||}
\hline \multirow{2}{*}{ Year } & \multicolumn{2}{|c|}{ \% infested bulbs } & \multicolumn{2}{c|}{$\%$ yield loss } \\
\cline { 2 - 5 } & $\begin{array}{c}\text { Infested bulbs } \\
\text { discarded }\end{array}$ & $\begin{array}{c}\text { Infested } \\
\text { bulbs } \\
\text { undiscarded }\end{array}$ & $\begin{array}{c}\text { Infested } \\
\text { bulbs } \\
\text { discarded }\end{array}$ & $\begin{array}{c}\text { Infested } \\
\text { bulbs } \\
\text { undiscarded }\end{array}$ \\
\hline \hline 2003 & 6.0 & 13.9 & 8.7 & 17.0 \\
\hline 2004 & 7.0 & 12.6 & 9.7 & 11.2 \\
\hline 2005 & 5.8 & 15.0 & 7.7 & 12.3 \\
\hline $\begin{array}{c}\text { Grand } \\
\text { mean }\end{array}$ & 6.3 & 13.8 & 8.7 & 13.5 \\
\hline
\end{tabular}

Table (4) : Effect of \% bulb infestation on yield loss . (Grand means for the three successive years 2003-2005).

\begin{tabular}{|c|c|c|c|}
\hline \multirow{2}{*}{$\begin{array}{c}\% \\
\text { infested bulbs }\end{array}$} & \multicolumn{3}{|c|}{ Months after storage } \\
\hline & $\begin{array}{c}1 \\
\text { (early July) }\end{array}$ & $\begin{array}{c}3 \\
\text { (early September) }\end{array}$ & $\begin{array}{c}5 \\
\text { (early November) }\end{array}$ \\
\hline 10 & 5.9 & 6.8 & 4.5 \\
\hline 20 & 10.9 & 13.0 & 14.6 \\
\hline 30 & 17.2 & 21.3 & 21.6 \\
\hline 40 & 21.3 & 29.5 & 30.6 \\
\hline 50 & 28.3 & 36.6 & 37.3 \\
\hline 60 & 34.3 & 42.5 & 42.9 \\
\hline 70 & 39.2 & 49.5 & 52.2 \\
\hline 80 & 48.5 & 56.7 & 59.9 \\
\hline 90 & 54.9 & 64.6 & 66.3 \\
\hline 100 & 62.5 & 72.1 & 76.5 \\
\hline $\mathrm{r}$ & 0.994 & 0.999 & 0.997 \\
\hline$b_{y \cdot x}$ & 0.63 & 0.72 & 0.77 \\
\hline
\end{tabular}

\section{REFERENCES}

Abd-El-Fattah T.A. (1980). Factors affecting the insect population during the storage of onion bulbs. M.Sc. Thesis, Fac. of Agric., Al-Azhar Univ., Egypt, 94 pp.

El-Shabrawy H.A. (1990). Studies on the ecology, biology and control of two onion bulb flies, Eumerus amoenus Loew., and Eumerus vestitus Bez.(Syrphidae, Diptera). M.Sc. Mikhael R.H. (1978). Biological studies on certain Thesis,Fac.of Agric.,Cairo Univ., Egypt,115 pp.

El-Shabrawy H.A. (1996). The role of carbon Mohamad K.K. (1973). Population dynamics of onion dioxide and irradiation in reducing the infestation of two onion bulb flies, Eumerus

(Diptera: Syrphidae). Ph.D. Thesis, Fac. of Agric., Cairo Univ. Egypt, 156 pp.

El-Sherif A.R.A. (1971). Studies on insects infesting onion and garlic in field and storage. Ph.D. Thesis, Fac. of Agric., Cairo Univ. Egypt, 279 pp.
Marcos G.P., Ernesto C.A., Alfonso A.P. and Jaime A.H.(1999). Eumerus strigatus(Fallen) (Diptera:Syrphidae)infesting Chilean Alliaceae. Agricultura Tecnica Santiago, 59 (2): 133-135.

Massry S.H.D. (2002). Ecological and bio-control studies on some pests infesting onion and garlic crops. M.Sc. Thesis, Fac. of Agric., Menoufia Univ., Egypt, 162 pp. onion flies and their control.M.Sc.Thesis, Fac. of Agric., Ain Shams Univ., Egypt, 95 pp. flies and their control. M.Sc Thesis, Fac of Agric., Assiut Univ., Egypt, 63 pp.

Mulin-Yu I. (1990). A dangerous pest of onion. Zashchita Rastenii Moskva, (3): 31-32.

Zabirov Sh.M. (1963). On the ecology of the onion bulb fly, Eumerus strigatus Fall. (Diptera, Syrphidae). (In Russian). Ent. Obozr., 42 pt.: 736743 Leningrad. (c.f. R.A.E., 54: 192-193, 1966). 
Eumerus amoenus Loew. (Diptera: Syrphidae)(صابة الأبصال المخزنة بذبابة البصل الكبيرة

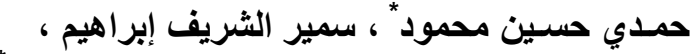

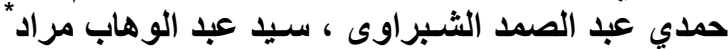

$$
\begin{aligned}
& \text { قسم علوم الحشرات الاقتصادية و المبيدات ـ كلية الزر اعة - جامعة القاهرة ـ الجيزة ـ مصر. } \\
& \text { * معهد بحوث وقاية النباتات ـ مركز البحوث الزر اعية ـ الدقي ـ الجيزة - مصر. }
\end{aligned}
$$

\section{ملخص بر من}

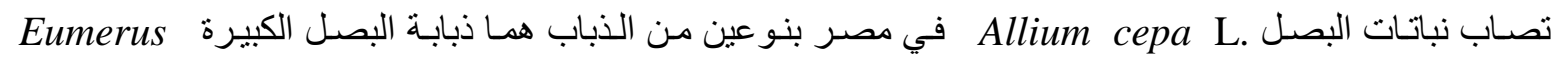

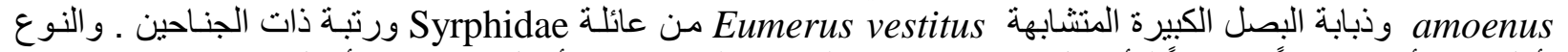

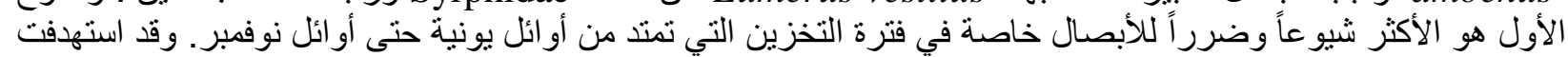

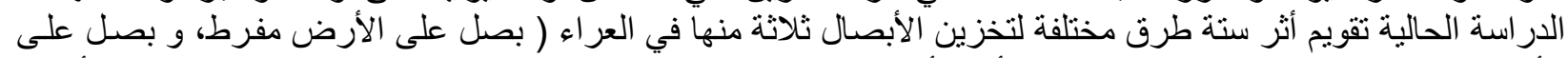

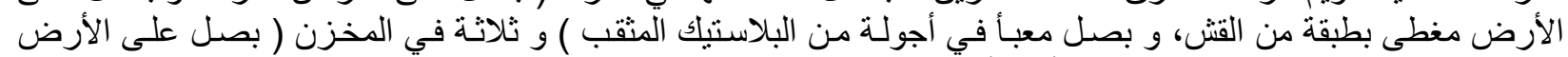

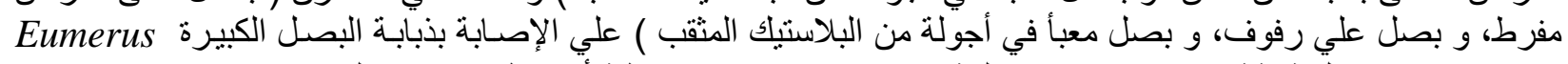

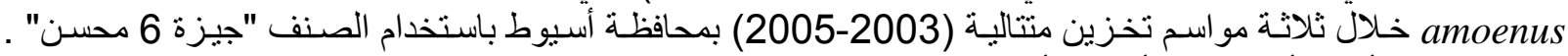

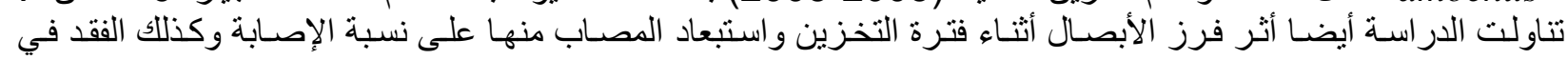

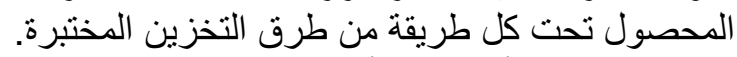

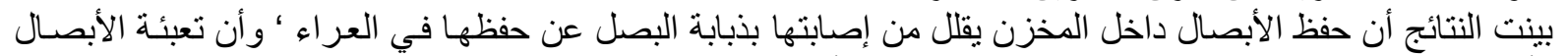

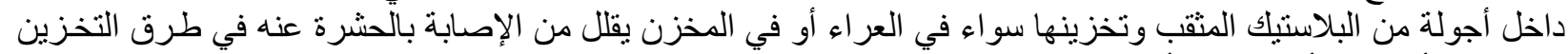

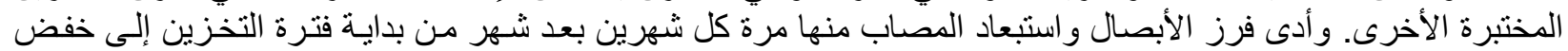

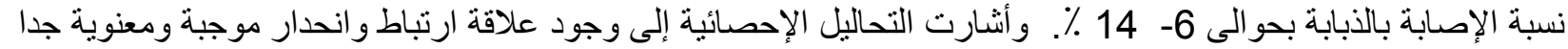

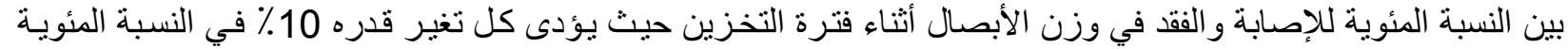

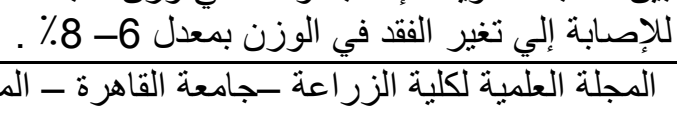

